\title{
Increased ethylene production by overexpressing phosphoenolpyruvate carboxylase in the cyanobacterium Synechocystis PCC 6803
}

\author{
Claudia Durall ${ }^{1}$, Pia Lindberg ${ }^{1}$, Jianping $\mathrm{Yu}^{2}$ and Peter Lindblad ${ }^{1 *}$ (1)
}

\begin{abstract}
Background: Cyanobacteria can be metabolically engineered to convert $\mathrm{CO}_{2}$ to fuels and chemicals such as ethylene. A major challenge in such efforts is to optimize carbon fixation and partition towards target molecules.

Results: The efe gene encoding an ethylene-forming enzyme was introduced into a strain of the cyanobacterium Synechocystis PCC 6803 with increased phosphoenolpyruvate carboxylase (PEPC) levels. The resulting engineered strain (CD-P) showed significantly increased ethylene production $\left(10.5 \pm 3.1 \mathrm{\mu g} \mathrm{mL}^{-1} \mathrm{OD}^{-1}\right.$ day $\left.{ }^{-1}\right)$ compared to the control strain $\left(6.4 \pm 1.4 \mu \mathrm{g} \mathrm{mL}^{-1} \mathrm{OD}^{-1}\right.$ day $\left.^{-1}\right)$. Interestingly, extra copies of the native pepc or the heterologous expression of PEPc from the cyanobacterium Synechococcus PCC 7002 (Synechococcus) in the CD-P, increased ethylene production (19.2 \pm 1.3 and $18.3 \pm 3.3 \mu \mathrm{g} \mathrm{mL}^{-1} \mathrm{OD}^{-1}$ day $^{-1}$, respectively) when the cells were treated with the acetyl-CoA carboxylase inhibitor, cycloxydim. A heterologous expression of phosphoenolpyruvate synthase (PPSA) from Synechococcus in the CD-P also increased ethylene production $\left(16.77 \pm 4.48 \mu \mathrm{g} \mathrm{mL}^{-1} \mathrm{OD}^{-1}\right.$ day $\left.^{-1}\right)$ showing differences in the regulation of the native and the PPSA from Synechococcus in Synechocystis.
\end{abstract}

Conclusions: This work demonstrates that genetic rewiring of cyanobacterial central carbon metabolism can enhance carbon supply to the TCA cycle and thereby further increase ethylene production.

Keywords: Cyanobacteria, Ethylene, Phosphoenolpyruvate carboxylase (PEPC), Phosphoenolpyruvate synthase (PPSA), Acetyl-CoA

\section{Background}

Cyanobacteria are the oldest organisms performing oxygenic photosynthesis. They appeared more than 2.5 billion years ago and were responsible for raising the oxygen levels in the atmosphere from being anoxic to about 20\% [1-3]. Cyanobacteria fix inorganic carbon mainly through the Calvin-Benson-Bassham cycle using the inefficient ribulose 1,5-bisphosphate carboxylase/

${ }^{*}$ Correspondence: peter.lindblad@kemi.uu.se

${ }^{1}$ Microbial Chemistry, Department of Chemistry-Ångström, Uppsala University, P.O. Box 523, 75120 Uppsala, Sweden

Full list of author information is available at the end of the article oxygenase ( $\mathrm{RuBisCO})$, a similar system as $\mathrm{C} 3$ plants $[4$, 5].

RuBisCO is the most abundant enzyme on earth and it can perform two competing reactions depending on the substrate used, either $\mathrm{CO}_{2}$ or $\mathrm{O}_{2}$ [6]. When RuBisCO performs the oxygenase reaction, where $\mathrm{O}_{2}$ is produced as a secondary product of the photosynthesis reactions, the metabolite produced (glyoxylate) is toxic for the cells, leading to losing both carbon and energy. This process is called photorespiration [7]. In order to overcome this reaction cyanobacteria have developed a carbon concentrating mechanism (CCM). The CCM consists in five different inorganic transporters (three for $\mathrm{HCO}_{3}{ }^{-}$and two

c) The Author(s) 2020. This article is licensed under a Creative Commons Attribution 4.0 International License, which permits use, sharing, adaptation, distribution and reproduction in any medium or format, as long as you give appropriate credit to the original author(s) and the source, provide a link to the Creative Commons licence, and indicate if changes were made. The images or other third party material in this article are included in the article's Creative Commons licence, unless indicated otherwise in a credit line to the material. If material is not included in the article's Creative Commons licence and your intended use is not permitted by statutory regulation or exceeds the permitted use, you will need to obtain permission directly from the copyright holder. To view a copy of this licence, visit http://creativeco mmons.org/licenses/by/4.0/. The Creative Commons Public Domain Dedication waiver (http://creativecommons.org/publicdomain/ zero/1.0/) applies to the data made available in this article, unless otherwise stated in a credit line to the data. 
for $\mathrm{CO}_{2}$ ), the carboxysome and the carbonic anhydrase. Cyanobacteria have survived in water environments due to the $\mathrm{CCM}$, overcoming low solubility of $\mathrm{CO}_{2}$ in water. In water, $\mathrm{CO}_{2}$ exists in equilibrium with bicarbonate and carbonate depending on $\mathrm{pH}$. Bicarbonate can diffuse into the carboxysome (a micro-compartment where RuBisCO is encapsulated together with the carbonic anhydrase) while $\mathrm{O}_{2}$ is blocked from entering the carboxysome. Inside the carboxysome, carbonic anhydrase converts bicarbonate into $\mathrm{CO}_{2}$ which can be used as substrate by $\mathrm{RuBisCO}$. When the product 3-phosphoglycerate is formed, it can diffuse out of the carboxysome and be further metabolized in the cytoplasm [8] (Fig. 1).

Cyanobacteria have the potential to mitigate the rising $\mathrm{CO}_{2}$ concentration in the atmosphere since they can function as green cell factories that recycle $\mathrm{CO}_{2}$. They are prokaryotic cells and relatively easy to genetically engineer, and as photoautotroph they are easy to grow with no competition of land between food production and biotechnological applications. Thus, these photosynthetic organisms are suitable for a sustainable production of substances of human interest $[9,10]$. Cyanobacteria have successfully been genetically engineered to produce different substances such as; fatty acids, omega 3-fatty acids, fatty alcohols, mannitol, lactic acid, hexoses, extracellular polysaccharides, ethanol, propanol, 1-butanol, isobutyraldehyde, isobutanol, isoprene, succinate, ethylene and others [11-14].

It has been shown that by engineering cyanobacteria for increased carbon fixation the cells grow faster with increased carbon fixation and biomass production [15, 16]. This can be combined with cells engineered to produce a selected compound. For instance, Synechococcus elongatus PCC 7942 (S. elongatus) was successfully genetically engineered to produce isobutyraldehyde and the overexpression of $\mathrm{RuBisCO}$ in the engineered strain enhanced the isobutyraldehyde production [13]. The overexpression of selected Calvin cycle genes increased ethanol production in the cyanobacterium Synechocystis PCC 6803 (Synechocystis) [15]. Furthermore, in a strain of S. elongatus engineered to produce 2,3-butanediol, additionally overexpressing enzymes in the pathway between the $\mathrm{RuBisCO}$ reaction and pyruvate (PYR) formation led to increased carbon fixation and biofuel production [17].

Given the inefficiency of RuBisCO, alternative carbon fixation pathways have been proposed. In 2014, a synthetic pathway based on the 3-hydroxypropionate bicycle was introduced into $S$. elongatus resulting in a bypass of the photorespiration [18]. In 2010, Bar-Even et al. [19] presented the malonyl-CoA-oxaloacetateglyoxylate (MOG) pathways, which theoretically are more efficient in fixing carbon than any existing native ones. Interestingly, the enzyme used in these pathways is phosphoenolpyruvate carboxylase (PEPc). PEPc is more efficient to fix carbon dioxide than RuBisCO and it is the enzyme used in $\mathrm{C} 4$ and CAM plants. The two most efficient MOG pathways identified were the C4-glyoxylate cycle/alanine option and the C4-glyoxylate cycle/lactate option. These two pathways are identical from step 1 to 6 and differ only in the last steps. As a first step towards implementing these pathways in Synechocystis, we overexpressed the native pepc and the three first enzymes (phosphoenolpyruvate synthase (PPSA), PEPc and malate dehydrogenase), which are all native in Synechocystis. Interestingly, the engineered strain overexpressing pepc showed a higher PEPc level, increased chlorophyll $a$ content and increased in vitro PEPc activity [20].

Ethylene is a precursor of polyethylene, polystyrene, PVC and even polyester, and its industrial production process (steam cracking) releases significant levels of $\mathrm{CO}_{2}$ [21]. Ethylene is also produced by plants and is an important signal molecule involved in germination, fruit ripening and senescence. There are three discovered pathways which synthesize ethylene in nature [22, 23]. In one of these, the Pseudomonas syringae ethylene-forming enzyme (Efe) requires only two substrates, 2-oxoglutarate and arginine, resulting in ethylene and succinate as products [21, 23, 24]. 2-Oxoglutarate is an intermediate of the tricarboxylic acid cycle (TCA cycle) and it is the signal molecule for the carbon status in the nitrogen metabolism [25]. efe has been heterologously expressed in cyanobacteria and it was believed to be unstable [26-28] until recent studies have demonstrated that the observed instability may be associated with the expression strategies rather than toxicity [29]. In addition, efe has been expressed in self-replicative vectors or integrated in the chromosome in different organisms, in Synechocystis and S. elongatus [21, 26, 30, 31] using different promoters [30-32], RBS [30, 33, 34] and increasing the number of copies of efe [33], all resulting in ethylene production. Ethylene production in engineered cyanobacteria is supported by drastic changes in carbon metabolism, including increased flux through PEPc [33]. Thus, increasing the capacity of this key enzyme and other relevant enzymes such as PPSA may lead to increased ethylene productivity.

The aim of this study was to test the hypothesis that genetic rewiring of central carbon metabolism can enhance carbon supply to TCA cycle and ethylene production by introducing efe into a Synechocystis strain overexpressing PEPc. The resulting ethylene-producing strain was further engineered to overexpress the native PPSA or PPSA from Synechococcus PCC 7002 (Synechococcus). In addition, extra copies of PEPc from Synechocystis and Synechococcus were also introduced. The engineered strains were cultivated with different 


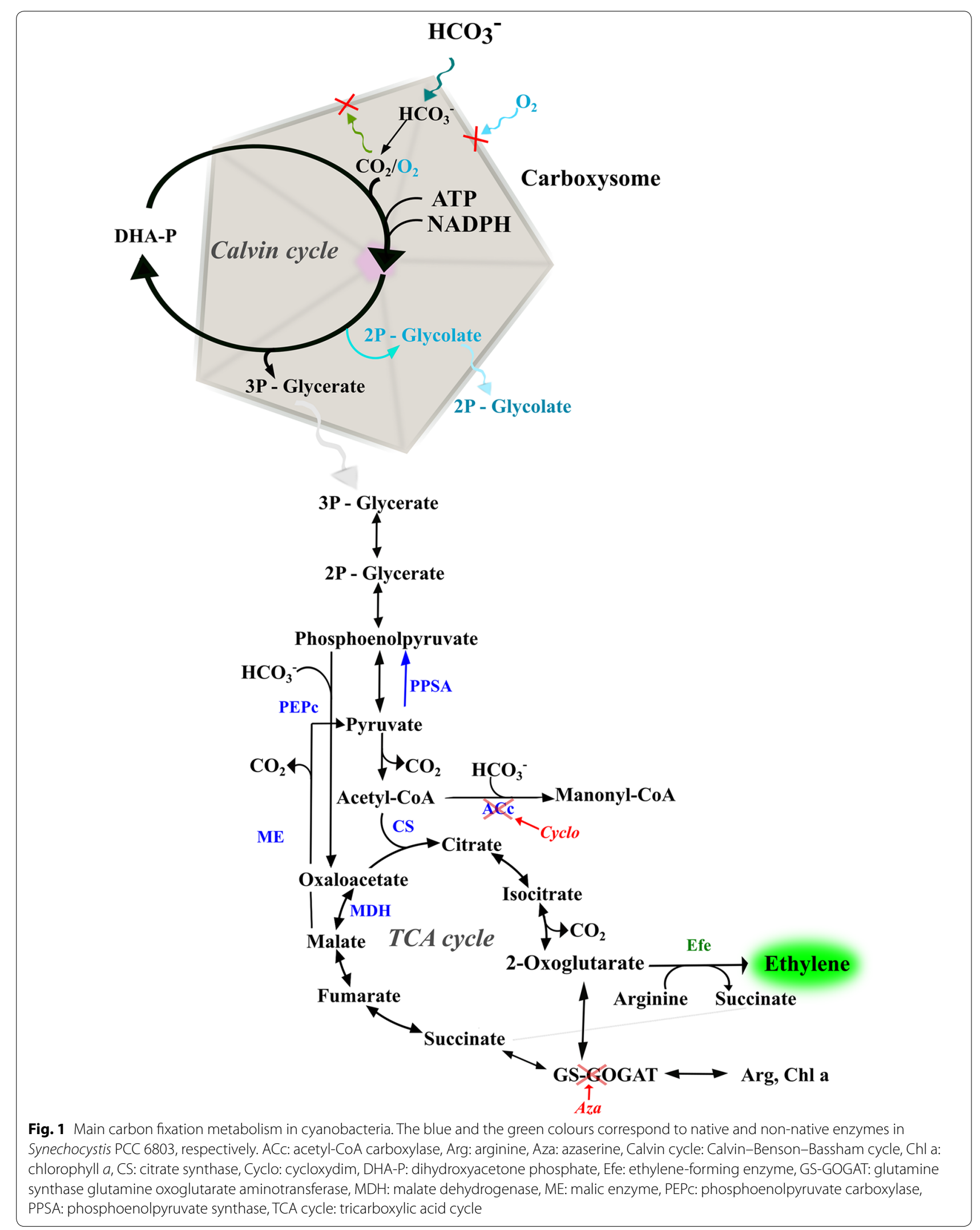


treatments in order to address limiting factors for ethylene production.

\section{Results}

\section{Expression of efe and engineered strains}

The efe from Pseudomonas syringae expressed in our strains was stable and expressed when the promoter (nrsB) was induced with $\mathrm{Ni}^{2+}$. The efe was introduced into two previously engineered strains containing one copy of the native pepc $\left(\mathrm{WT}+\mathrm{Km}^{\mathrm{r}}[20]\right)$ and three copies of the native pepc (WT $+2 x P E P c$ [20]), creating CD-C and $C D-P$ strains, respectively. The CD-P strain was further engineered with another copy of the native pepc $(4 \times p e p c, \mathrm{CD}-\mathrm{P} 1)$, one extra copy of the native ppsa $(3 \times$ pepc, $2 \times$ ppsa, CD-P2) and an extra copy of the native pepc and ppsa $(4 \times$ pepc, $2 \times$ ppsa, CD-P3). The same strategy was used but with the heterologous expression of PEPc and PPSA from the cyanobacterium Synechococcus PCC 7002, creating CD-P4 $(3 \times$ native pepc, $1 \times$ pepc PCC 7002), CD-P5 (3× native pepc, $1 \times$ ppsa PCC 7002) and CD-P6 $(3 \times$ native pepc, $1 \times$ pepc $\mathrm{PCC} 7002,1 \times$ ppsa PCC 7002). The engineered strains containing efe and additional modifications are summarized in Table 2.

\section{Ethylene production}

Under the standard treatment $(\mathrm{BG} 11+50 \mathrm{mM}$ Tris $\mathrm{pH}$ 8.0, $50 \mathrm{mM} \mathrm{NaHCO}, \mathrm{Km}\left(25 \mu \mathrm{g} \mathrm{mL}{ }^{-1}\right)$ and $\mathrm{Cm}$ $\left(20 \mu \mathrm{g} \mathrm{mL}^{-1}\right), 5 \mu \mathrm{M}$ of $\mathrm{NiCl}_{2}$ and $20 \mu \mathrm{E} \mathrm{m}^{-2} \mathrm{~s}^{-1}$, WT and the control engineered strain without the efe (CD-E) did not produce any ethylene regardless of $\mathrm{Ni}^{2+}$ induction (Fig. 2). The engineered strains containing efe did not show ethylene production when the cells were not induced (data not shown). However, when the engineered strains were induced with $\mathrm{NiCl}_{2}(5 \mu \mathrm{M})$ the cells produced ethylene (Fig. 2). Interestingly, significantly higher ethylene productivity was observed in the engineered strain with increased copy numbers of pepc (three copies) (CD-P, $10.5 \pm 3.1 \mu \mathrm{g} \mathrm{mL}{ }^{-1} \mathrm{OD}^{-1}$ day $^{-1}$ ) compared to cells with WT levels of PEPc (one copy) (CDC) $\left(6.4 \pm 1.4 \mu \mathrm{g} \mathrm{mL}^{-1} \mathrm{OD}^{-1} \mathrm{day}^{-1}\right)(p=0.002)$ (Fig. 2). When an additional copy of the native pepc was introduced in the strain CD-P, leading to the CD-P1 engineered strain, no significant differences of ethylene production was observed $\left(13.5 \pm 3.7 \mu \mathrm{g} \mathrm{mL}^{-1} \mathrm{OD}^{-1}\right.$ day ${ }^{-}$ $\left.{ }^{1}\right)$. The same result was observed when the native PPSA was overexpressed in the CD-P alone or together with another extra copy of PEPc creating CD-P2 and CD-P3 producing $8.0 \pm 2.2$ and $12.4 \pm 5.7 \mu \mathrm{g} \mathrm{mL}^{-1} \mathrm{OD}^{-1}$ day $^{-1}$, respectively. No significant differences in

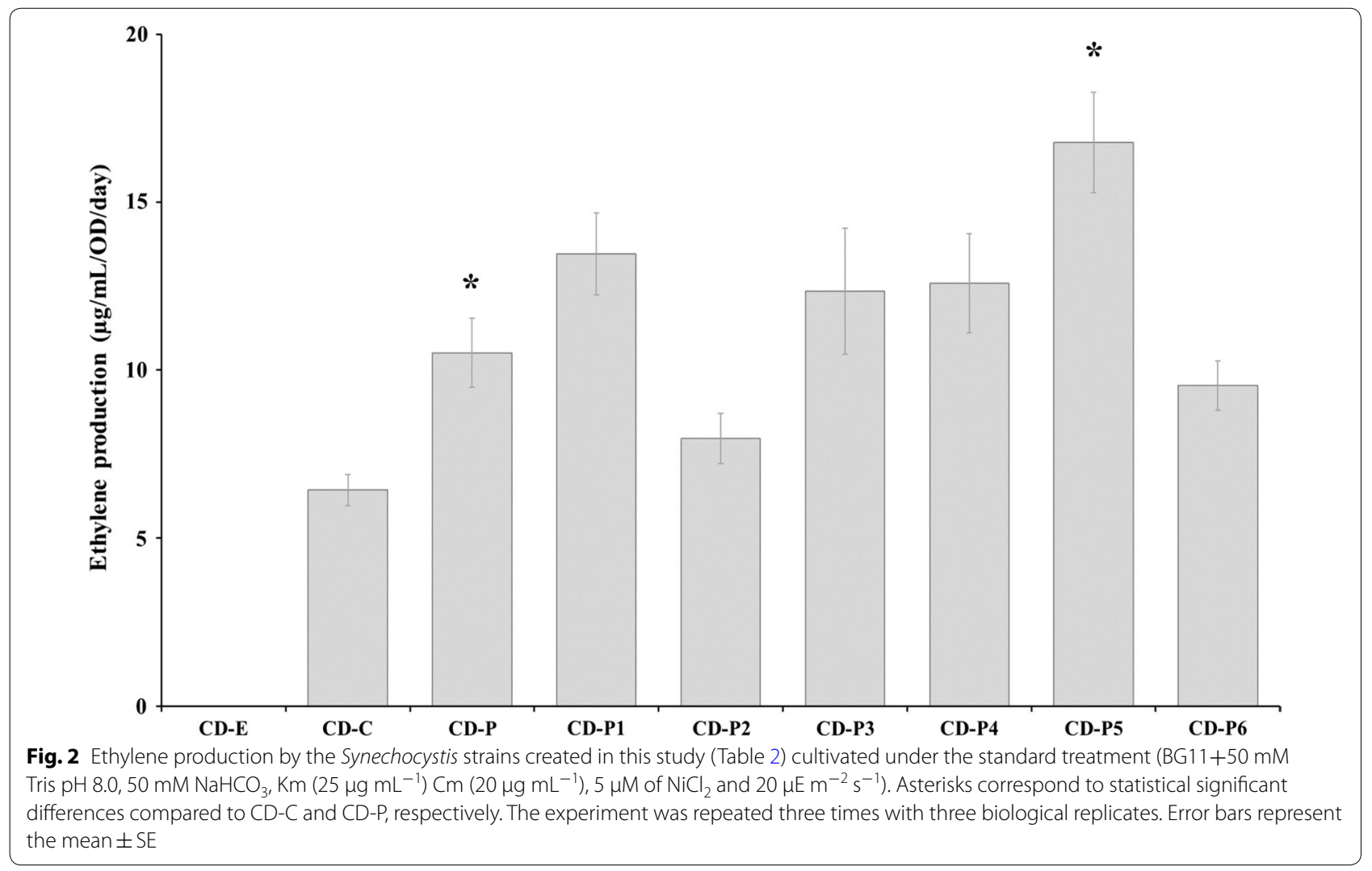


ethylene production were observed between the control strain CD-P and the engineered strains containing the PEPc from the cyanobacterium Synechococcus, CD-P4 $\left(12.6 \pm 4.4 \mu \mathrm{g} \mathrm{mL} \mathrm{OD}^{-1}\right.$ day $\left.^{-1}\right)$ and the PEPc and PPSA from Synechococcus, CD-P6 $\left(9.5 \pm 2.2 \mu \mathrm{g} \mathrm{mL}^{-1} \mathrm{OD}^{-1}\right.$ day $\left.^{-1}\right)$. Interestingly, a significant increase in ethylene production was observed when the PPSA from Synechococcus was expressed in the CD-P creating the CD-P5 $\left(16.8 \pm 4.5 \mu \mathrm{g} \mathrm{mL}^{-1} \mathrm{OD}^{-1}\right.$ day $\left.^{-1}\right)$ engineered strain compared to the control strain CD-P $(p=0.003)$ (Fig. 2).

The ethylene production of the engineered strain, CD-P when different treatments were applied (Table 3) did not show significant differences when BG11+arginine (one of the substrates of Efe) $\left(12.0 \pm 3.9 \mu \mathrm{g} \mathrm{mL}{ }^{-1} \mathrm{OD}\right.$ ${ }^{-1}$ day $^{-1}$ ), BG11+cycloxydim (inhibitor of acetyl-CoA carboxylase, [35]) $\left(9.5 \pm 4.1 \mu \mathrm{g} \mathrm{mL} \mathrm{m}^{-1} \mathrm{OD}^{-1}\right), \mathrm{BG}_{1}$ $\left(10.4 \pm 2.7 \mu \mathrm{g} \mathrm{mL}^{-1} \mathrm{OD}^{-1} \mathrm{day}^{-1}\right), \quad B G 11_{0}+$ arginine $\left(8.0 \pm 3.4 \mu \mathrm{g} \mathrm{mL}^{-1} \mathrm{OD}^{-1}\right.$ day $\left.^{-1}\right)$ and $\mathrm{BG}^{-1} 1_{0}+$ cycloxydim $\left(8.4 \pm 4.2 \mu \mathrm{g} \mathrm{mL}^{-1} \mathrm{OD}^{-1}\right.$ day $\left.^{-1}\right)$ compared to the standard treatment, BG11 $\left(10.7 \pm 2.3 \mu \mathrm{g} \mathrm{mL}^{-1} \mathrm{OD}^{-1}\right.$ day $\left.^{-1}\right)$ (Fig. 3). However, when the cells were treated with BG11+azaserine (an inhibitor of the GS-GOGAT,
35) and BG11+arginine, azaserine and cycloxy$\mathrm{dim}$, the ethylene productivity decreased significantly to $5.7 \pm 2.9 \mu \mathrm{g} \mathrm{mL} \mathrm{mL}^{-1} \mathrm{OD}^{-1}$ day $^{-1}(p=0.007)$ and $6.1 \pm 0.8 \mu \mathrm{g} \mathrm{mL}^{-1} \mathrm{OD}^{-1}$ day $^{-1}(p=0.001)$, respectively, compared to the standard treatment, BG11 $\left(10.7 \pm 2.3 \mu \mathrm{g} \mathrm{mL}^{-1} \mathrm{OD}^{-1}\right.$ day $\left.^{-1}\right)$ (Fig. 3).

Interestingly, when the engineered strains were incubated with BG11+cycloxydim, no significant differences were observed in ethylene production (data not shown) compared to the standard treatment, BG11, except for the CD-P1 and CD-P4 engineered strains (Fig. 4). CD-P1 and CD-P4 showed significant increased ethylene productivity $(19.2 \pm 1.3$ and $18.3 \pm 3.3 \mu \mathrm{g} \mathrm{mL}^{-1} \mathrm{OD}^{-1}$ day $^{-1}$, respectively) compared to the standard treatment $(p=0.002$ and $p=0.002$, respectively) (Fig. 4).

\section{Efe and PPSA protein levels}

The control strain without efe showed no expression of Efe (CD-E) while the Efe protein level was similar in all the induced engineered strains containing efe (Table 2) under standard treatment (Fig. 5). The tagged Flag-PPSA

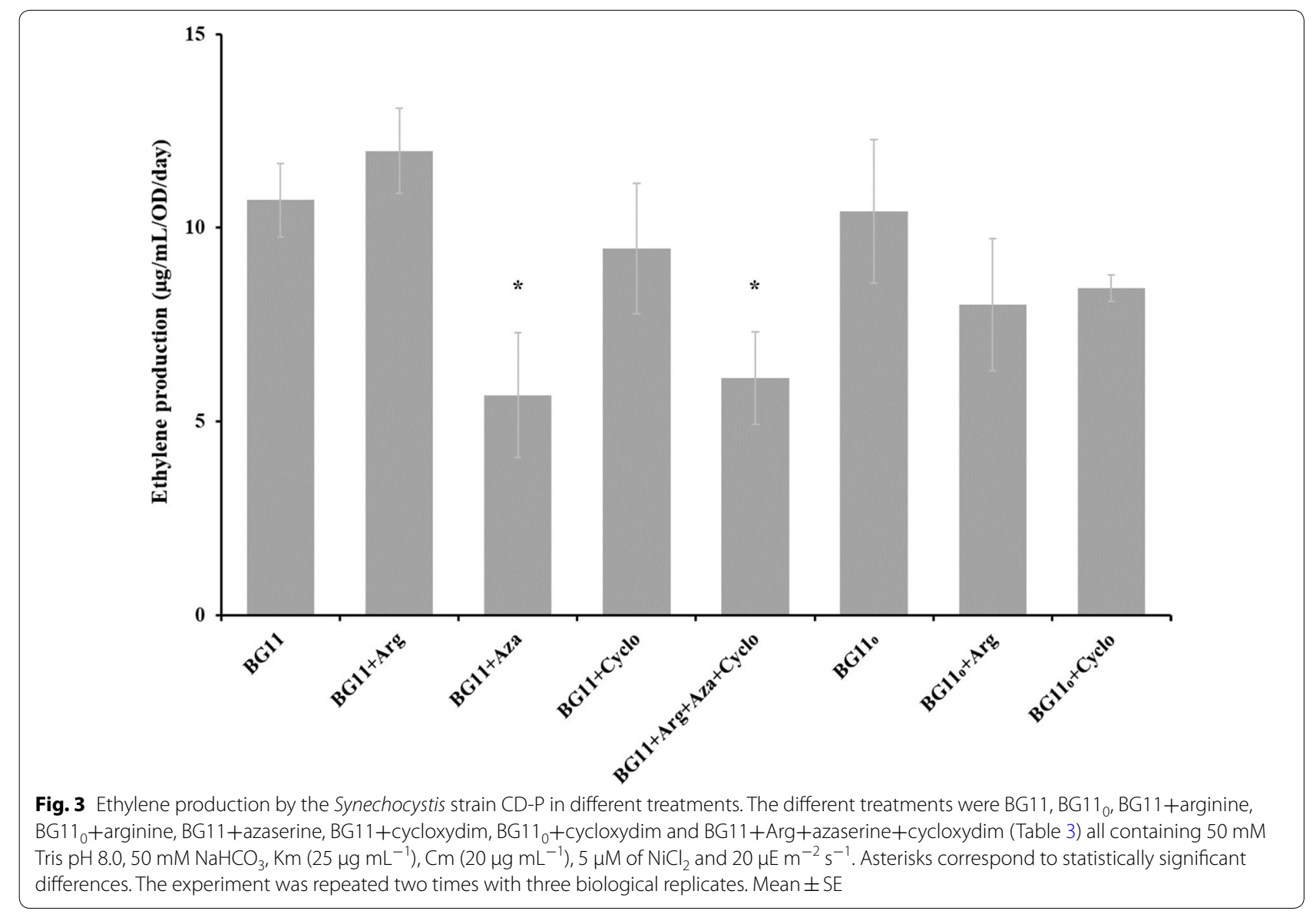




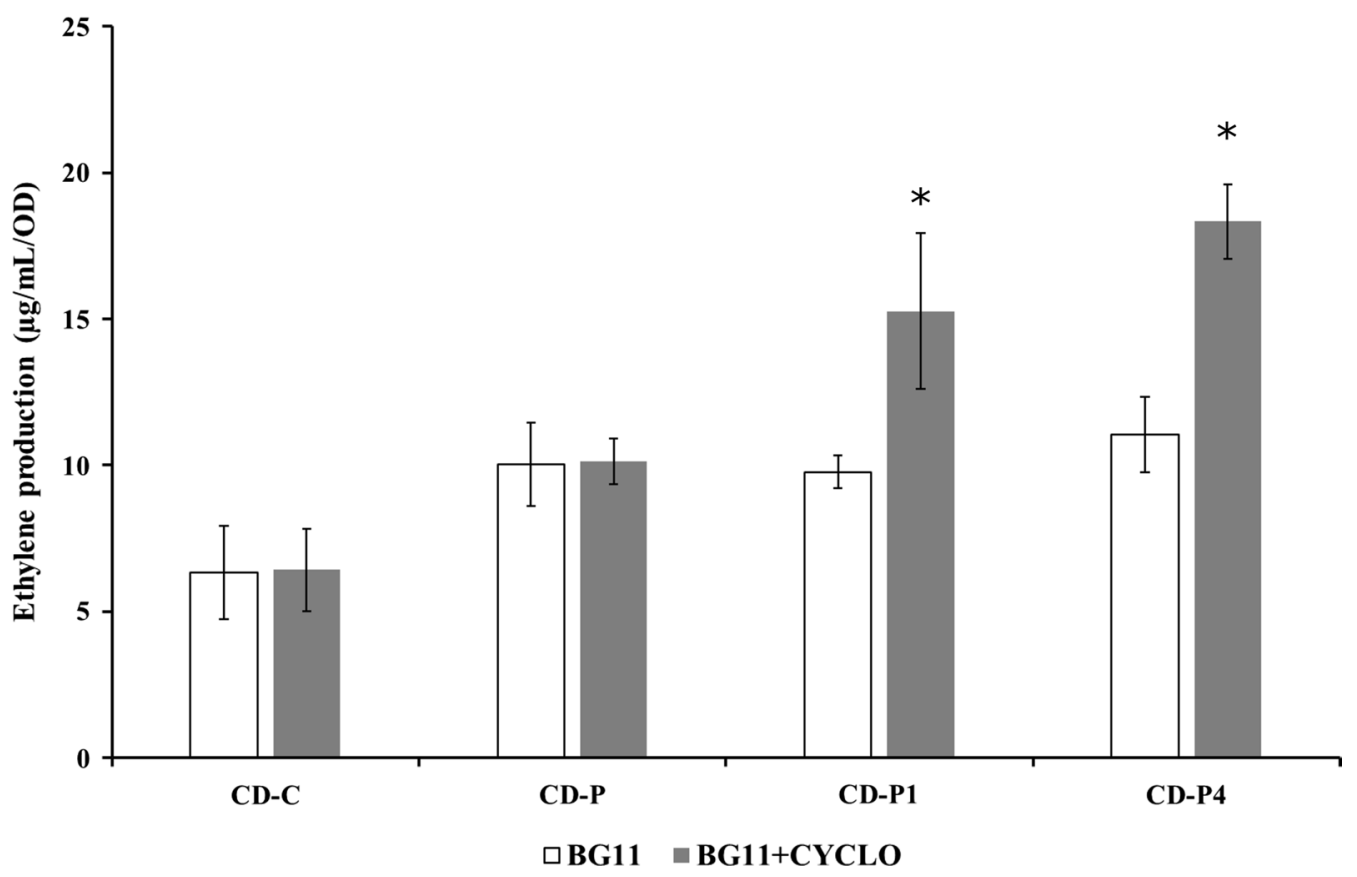

Fig. 4 Ethylene production of the Synechocystis strains, CD-C, CD-P, CD-P1 and CD-P4 in standard and BG11+cycloxydim treatment (Table 3). Asterisks correspond to statistical significant differences. The experiment was repeated twice with three biological replicates. Mean \pm SE

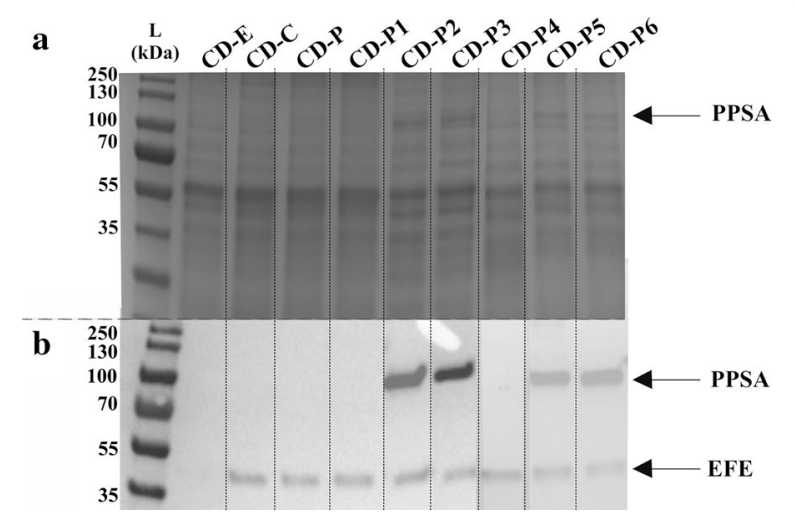

Fig. 5 SDS-PAGE/Western immunoblot of the Synechocystis strains created in this study (Table 2) analysed for the presence of phosphoenolpyruvate synthase (PPSA) and ethylene-forming enzyme (EFE). A SDS-PAGE loaded with $3 \mu \mathrm{g}$ of protein crude extract from the Synechocystis strains created in this study under standard treatment (Table 2) and B Western immunoblot using anti-Flag antibody for the Synechocystis engineered strains (Table 2) under standard treatment. Standard treatment is BG11+50 mM Tris pH 8.0, $50 \mathrm{mM} \mathrm{NaHCO}_{3}, \mathrm{Km}\left(25 \mu \mathrm{g} \mathrm{mL}^{-1}\right), \mathrm{Cm}\left(20 \mu \mathrm{gL}^{-1}\right)$ and $5 \mu \mathrm{M}$ of $\mathrm{NiCl}_{2}$ and $20 \mu \mathrm{E} \mathrm{m}^{-2} \mathrm{~s}^{-1}$. The upper band corresponds to PPSA (approximate molecular weight 91.17 and $92.56 \mathrm{kDa}$ for PPSA 6803 and PPSA 7002 , respectively) and the lower band to EFE (approximate molecular weight $42.16 \mathrm{kDa}$ )

was expressed only in the engineered strains (CD-P2, CD-P3, CD-P5, CD-P6) containing PPSA from either Synechocystis or Synechococcus (Fig. 5).
When the engineered strain CD-P was incubated with the different treatments, the Efe protein level was similar with the exception of BG11+arginine and the presence of cycloxydim regardless of the presence of nitrate (BG11+cycloxydim and BG11 0 +cycloxydim, Fig. 6). The presence of cycloxydim and arginine in the presence of nitrate increased the Efe protein expression (Fig. 6).

\section{PEPc protein level}

The PEPc protein level increased with increased number of PEPc copies (Fig. 7). Interestingly, the PEPc protein levels were not affected by the location of the gene in the expression construct, as the levels were similar when the PEPc was expressed alone (CD-P1 and CD-P4) and in the second position in an operon (CD-P3, CD-P6) (Fig. 7). Higher PEPc protein content was observed in the engineered strains expressing PEPc from Synechococcus (CDP4 and CD-P6) than Synechocystis (CD-P1 and CD-3) (Fig. 7). However, the affinity of the antibody towards the PEPc from Synechococcus was higher than the PEPc from Synechocystis ( $\mathrm{PEPc}_{6803}$ and $\mathrm{PEPc}_{7002}$ - Fig. 7).

\section{Discussion}

Prior efforts in developing ethylene-producing cyanobacterial strains focused on overcoming genetic instability and increasing Efe expression levels [21, 29, 33, 34]. Here, we show that genetic rewiring of central carbon 


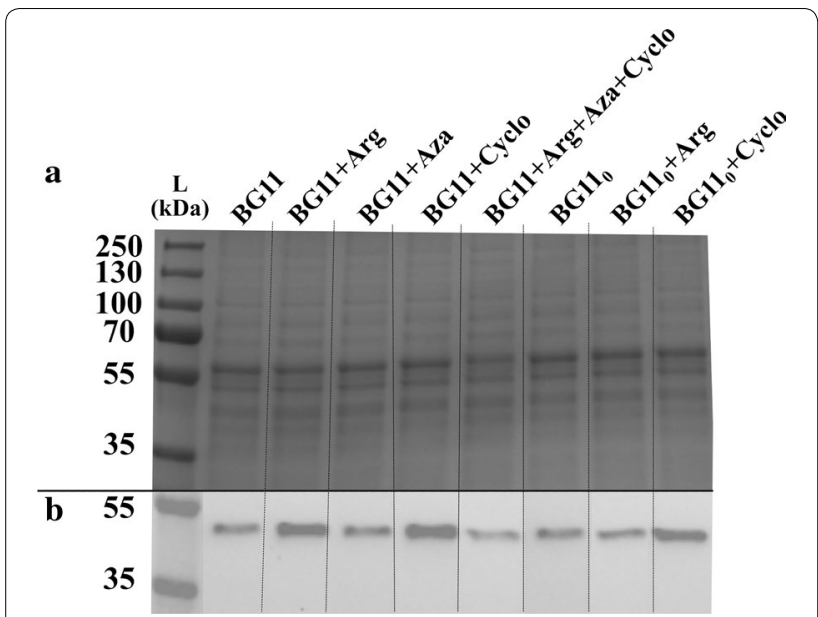

Fig. 6 SDS-PAGE/Western immunoblot of the Synechocystis strains created in this study (Table 2) analysed for the presence of ethylene-forming enzyme (EFE). A SDS-PAGE loaded with $3 \mu \mathrm{g}$ of protein crude extract from the Synechocystis engineered strain CD-P in different treatments (Table 3) and B Western immunoblot using anti-Flag antibody from the Synechocystis engineered strain CD-P in different treatments tested (Table 3). The different treatments were $\mathrm{BG} 11, \mathrm{BG} 11_{0}, \mathrm{BG} 11$ +arginine, $\mathrm{BG} 11_{0}$ + arginine, $\mathrm{BG} 11$ +azaserine, BG11+cycloxydim, BG11 + +cycloxydim and BG11+arginine+azase rine+cycloxydim (Table 3) all containing $50 \mathrm{mM}$ Tris pH 8.0, $50 \mathrm{mM}$ $\mathrm{NaHCO}_{3}, \mathrm{Km}\left(25 \mu \mathrm{g} \mathrm{mL}^{-1}\right), \mathrm{Cm}\left(20 \mu \mathrm{g} \mathrm{mL}^{-1}\right), 5 \mu \mathrm{M}$ of $\mathrm{NiCl}_{2}$ and $20 \mu \mathrm{E} \mathrm{m}^{-2} \mathrm{~s}^{-1}$

metabolism can enhance carbon supply to TCA cycle and thereby ethylene productivity.

Other studies have observed that overexpressing PEPc increases the levels of TCA cycle intermediates, for instance, succinate [36, 37]. In 2016, we observed a higher chlorophyll $a$ concentration in the cells overexpressing
PEPc [20]. Since chlorophyll $a$ is synthesized from glutamate, which in turn is formed by 2-oxoglutarate and glutamine, our hypothesis was that this engineered strain had higher 2-oxoglutarate levels and may have the potential of increased ethylene production. The differences in ethylene productivity between CD-C and CD-P were only observed when bicarbonate was present in the media (data not shown). These results suggest that $\mathrm{CO}_{2}$ was limiting in the vials, and with bicarbonate addition higher carbon fixation was present in CD-P compared to $\mathrm{CD}-\mathrm{C}$ resulting in increased ethylene productivity in the CD-P strain.

Interestingly, the overexpression of the native Synechocystis PPSA and the heterologous expression of PPSA from Synechococcus resulted in differences in ethylene production (CD-P2 and CD-P5, Fig. 2). The DNA and amino acid identity between these proteins are 70.5 and $76.6 \%$, respectively. Little is known about PPSA. It might be that the differences observed in ethylene production are caused by differences in the amino acids sequences in the region located at the $\mathrm{N}$-terminus where ATP is predicted to bind and/or the C-terminus where PYR is predicted to bind, or on the insertion (14 amino acids) present in PPSA from Synechococcus (145-160 PPSA PCC 7002 numbering, Additional file 1: Figure S1, Uniprot P23538). According to our own experience, expressing not an exact copy of the native gene (either a codon-optimized version or from another cyanobacterial strain), a heterologous expression of a protein leads to different activities and, not unlikely, regulation than of the native enzyme. Thus, these two proteins may have different kinetics and regulation, leading to different behaviour in the metabolism of Synechocystis. In addition, the

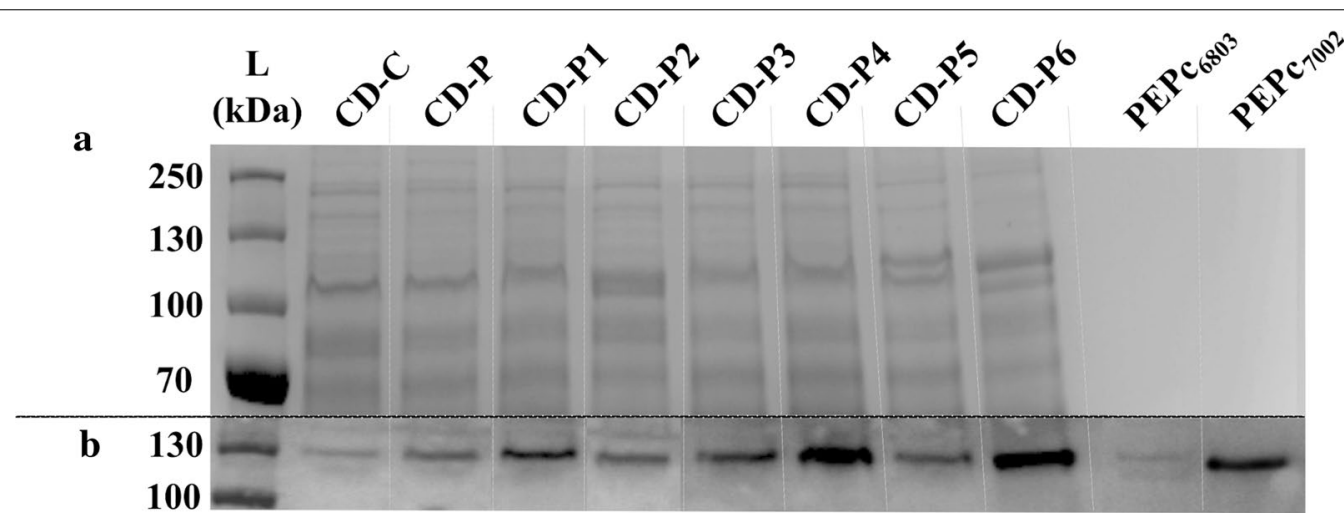

Fig. 7 SDS-PAGE/Western immunoblot of the Synechocystis strains created in this study (Table 2) analysed for the presence of phosphoenolpyruvate carboxylase (PEPC). A SDS-PAGE loaded with $31 \mu \mathrm{g}$ of protein crude extract from Synechocystis strains created in this study under standard treatment (Table 2) and B Western immunoblot using anti-PEPc for the Synechocystis engineered strains (Table 2) in standard treatment. Standard treatment is BG1 1+ $50 \mathrm{mM}$ Tris pH 8.0, $50 \mathrm{mM} \mathrm{NaHCO}_{3}, \mathrm{Km}\left(25 \mu \mathrm{g} \mathrm{mL}^{-1}\right), \mathrm{Cm}\left(20 \mu \mathrm{g} \mathrm{mL}^{-1}\right), 5 \mu \mathrm{M} \mathrm{of} \mathrm{NiCl}$ and $20 \mu \mathrm{E} \mathrm{m}{ }^{-2} \mathrm{~s}^{-1}$. $\mathrm{PEPC}_{6803}$ and PEPC 7002 corresponds to purified protein (100 ng loaded) of PEPc from Synechocystis PCC 6803 and Synechococcus PCC 7002, respectively 
lower production of ethylene in the CD-P6 strain compared to CD-P5 may be attributed to that when PPSA PCC 7002 is expressed, much of the phosphoenolpyruvat (PEP) component is converted to PYR. However, when PEPc and PPSA PCC 7002 are expressed, less amount of PEP is converted to PYR, then limiting the amount of acetyl-CoA and therefore the carbon flux into the TCA cycle. In order to discover which are the bottlenecks for ethylene production, we decided to investigate the effect of increasing the concentrations of the two substrates of Efe, 2-oxoglutarate and arginine. It has been observed that addition of 2-oxoglutarate did not increase ethylene production in Synechocystis but it did in Synechococcus [38]. In addition, it is known that when cultivating the cells without a nitrogen source, the 2-oxoglutarate levels increase when a switch in metabolism occurs [21, 39, 40]. A decreased ethylene productivity in an engineered Synechocystis strain when the cells were cultivated over several days under nitrogen starvation has been reported [21], however we did not observe this effect in our $24 \mathrm{~h}$ incubation (Fig. 3). We also tested the addition of azaserine, which blocks the glutamine amino transferase needed for the GS-GOGAT cycle and therefore increases the 2-oxoglutarate levels [39]. However, less ethylene production was observed in our experiments (Fig. 3), which may be due to arginine metabolism being affected by inhibiting the GS-GOGAT cycle.

In agreement with an earlier study [38], the addition of arginine did not increase the ethylene productivity, thus this amino acid is not a limiting substrate in the engineered strains under our standard treatment. However, when in the same study 2-oxoglutarate and arginine were both added to the cells, ethylene productivity was increased [38]. Thus, the combination of both substrates enhances the ethylene production. However, when we incubated the engineered strain CD-P with $\mathrm{BG}_{1} 1_{0}+$ arginine, where the nitrogen levels were very low which should lead to enhanced levels of 2-oxoglutarate, no differences were observed compared to the standard treatment (Fig. 3). It has been reported that nitrogen starvation (and other nutrient stresses) and arginine enhances the production of the nitrogen storage compound cyanophycin [41] and therefore arginine may not have been available for the Efe reaction under this treatment. Ethylene production is also accompanied by accumulation of guanidine inside cyanobacterial cells and in the medium, leaving less nitrogen available for arginine regeneration [42]. More research will be needed to understand the regulation of arginine metabolism in cyanobacteria, and to develop new strategy for improving ethylene production.

Overexpressing PEPc may decrease the amount of PEP. However, it is known that a significant amount of PYR (which can be converted to acetyl-CoA, Fig. 1) is provided by the "C4-like cycle", which involves PPSA, PEPc, malate dehydrogenase and the malic enzyme [43]. Flux through this pathway is stimulated by ethylene production [33]. Our results further demonstrate that expanding this pathway capacity by enzyme overexpression leads to increased ethylene productivity. Citrate synthase (CS) has a higher affinity for oxaloacetate (the product of PEPc) than acetyl-CoA [44], so if less acetyl-CoA was available, the CS may not catalyse the reaction. Thus, this indicates that acetyl-CoA is either a limiting compound for ethylene production or enhances the PEPc activity (since it is an activator of PEPc [45], when the cells have been engineered with very high levels of PEPc and treated with cycloxydim (CD-P1 and CD-P4) (Fig. 4). Even though the DNA and amino acid sequence showed identities of 66.2 and $63.9 \%$, respectively, and the carboxylases seem to be relatively similar, the in vitro PEPc activity from Synechococcus (unpublished) is higher than the activity of PEPc from Synechocystis [45], the heterologous activity of the carboxylase may be subject to limitations in substrate availability of Synechocystis and therefore no significant differences were observed in ethylene production between CD-P1 and CD-P4.

It was previously described that the Efe protein level was a limiting factor in ethylene production [30, 33]. However, in the engineered strain CD-P, it seems that the level of Efe protein is not limiting ethylene production since the presence of cycloxydim, and possibly increased acetyl-CoA or arginine, upregulated the Efe protein levels without increased ethylene production (Fig. 3). Thus, in this engineered strain and test conditions, other factors limit the production of ethylene.

\section{Conclusions}

In conclusion, genetic rewiring of cyanobacterial central carbon metabolism via overexpression of PEPc and PPSA increased ethylene productivity in Synechocystis engineered for the production of ethylene via an introduced Efe. This strategy can be incorporated into strain development for cyanobacterial production of ethylene, as well as of other products derived from the TCA cycle.

\section{Methods}

\section{Construction of plasmids}

To amplify the ethylene gene (efe)-Flag tagged, 1-10 ng of plasmid pJU158 [33] (quantified using a Nanodrop 2000 Spectrophotometer, Thermo Scientific) and for amplification of the native genes PEPc and PPSA, 50-250 ng of genomic DNA from Synechocystis or Synechococcus was used for the Phusion High-Fidelity Hot Spot II DNA polymerase (Finnzymes) as template together with gene-specific primers (Additional file 1: Table S1). The 
polymerase chain reaction (PCR) products were purified using the Gene JET Purification kit (from Thermo Scientific). Obtained PCR products, the plasmid pEERM3+ (plasmid recombining with the neutral site I of Synechocystis and containing the $n r s B$ promoter [46, 47] and the plasmid pPMQAC1 (self-replicative plasmid containing the native psbA2 promoter) were digested by selected restriction enzymes (Fermentas) and purified using the DNA clean \& concentration ${ }^{\text {TM }}-5$ from Zymo. Digested PCR product and plasmid were then ligated using the Quick Ligation ${ }^{\mathrm{TM}}$ Kit (New England Biolabs) and kept at room temperature for $15 \mathrm{~min}$. The plasmids created are summarized in Table 1.

\section{Transformation of Escherichia coli DH5a}

5-6 $\mu \mathrm{L}$ of the ligated DNA product was mixed with $50 \mu \mathrm{L}$ of thawed ice cold competent cells of E. coli DH5 $\alpha$. The tube was incubated on ice for $30 \mathrm{~min}$. After that, the tube was placed at $42{ }^{\circ} \mathrm{C}$ for $1 \mathrm{~min}$ and incubated on ice again for 5 more min. $450 \mu \mathrm{L}$ of Luria-Bertani (LB) medium at room temperature was added and mixed. The cells were then incubated at $37^{\circ} \mathrm{C}$ for $1 \mathrm{~h}$. Finally, the cells were centrifuged at $13,300 \mathrm{rpm}$ for $2 \mathrm{~min}$ and $450 \mu \mathrm{L}$ of supernatant was discarded. The remaining supernatant was used to resuspend the cells and spread them onto a LB agar plate containing spectinomycin $\left(\mathrm{Sp}, 50 \mu \mathrm{g} \mathrm{mL}^{-1}\right)$ or chloramphenicol $\left(\mathrm{Cm}, 20 \mu \mathrm{g} \mathrm{mL}^{-1}\right)$ before placed overnight at $37^{\circ} \mathrm{C}$.

Overnight colonies were used to run a PCR in order to verify if they had incorporated the genetic construct. Dream Taq DNA polymerase protocol from Fermentas was used together with the primers described above (2.1.). The positive colonies were grown with $\mathrm{LB}$ media containing either $\mathrm{Sp}\left(50 \mu \mathrm{g} \mathrm{mL}^{-1}\right)$ or $\mathrm{Cm}\left(20 \mu \mathrm{g} \mathrm{mL}^{-1}\right)$ and incubated shaking, at $37{ }^{\circ} \mathrm{C}$ overnight. Next day, the plasmid was extracted from the cells using the JET Plasmid Miniprep kit from Thermo Scientific. The purified plasmid was sent for sequencing (Eurofins) and when it was confirmed to be correct they were transformed or conjugated to the previously engineered Synechocystis strains (WT+Km ${ }^{\mathrm{r}}$ and WT+2xPEPc [20] for transformation, and CD-P for conjugation).

\section{Transformation of Synechocystis}

Synechocystis cells overexpressing the native phosphoenolpyruvate carboxylase (PEPc) (WT+2xPEPc) or containing the kanamycin $(\mathrm{Km})$ antibiotic cassette $\left(\mathrm{WT}+\mathrm{Km}^{\mathrm{r}}\right)$ were grown in BG11 medium with $\mathrm{Km}$ $\left(50 \mu \mathrm{g} \mathrm{mL}^{-1)}\right.$ for $2-3$ days. When the cells reached $\mathrm{OD}_{750}$ around 0.3 (determined using a Varian 50 Bio UV-Visible Spectrophotometer), $10 \mathrm{~mL}$ of cells were then harvested by centrifugation ( $5000 \mathrm{rpm}$ for $10 \mathrm{~min}$ at $20^{\circ} \mathrm{C}$ ). The pellet was resuspended in $250 \mu \mathrm{L}$ of BG11. $100 \mu \mathrm{L}$ of cells were then mixed with $1 \mu \mathrm{g}$ of plasmid. The mixture was incubated $4-6 \mathrm{~h}$ in low light at $30{ }^{\circ} \mathrm{C}$. The cells were spread on a nitrocellulose filter on top of BG11 agar plates. After approximately $24 \mathrm{~h}$, the filters were changed to a BG11 plate containing $\mathrm{Km}\left(25 \mu \mathrm{g} \mathrm{mL}^{-1}\right)$ and $\mathrm{Sp}$ $\left(10 \mu \mathrm{g} \mathrm{mL} \mathrm{L}^{-1}\right)$. Positive colonies were confirmed by PCR and re-streaked on plates with increased Sp concentration (up to $50 \mu \mathrm{g} \mathrm{mL}^{-1}$ ) until PCR did not show any band corresponding to the native neutral site sequence. The cells were grown only with kanamycin for 2 weeks and a PCR confirmed that the ethylene construct was fully segregated. The engineered strains are summarized in Table 2.

\section{Conjugation}

$1 \mathrm{~mL}$ of $E$. coli cells containing the desired plasmids and $1 \mathrm{~mL}$ of E. coli (pRL443) were grown overnight at $37^{\circ} \mathrm{C}$

Table 1 Plasmids used/constructed in this study

\begin{tabular}{|c|c|c|c|c|c|}
\hline Plasmid & Promoter & Gene expressed & $\begin{array}{l}\text { Resistant } \\
\text { cassette }\end{array}$ & Integration site & References \\
\hline pEERM & psbA2 & - & $\mathrm{Km}$ & psbA2 & {$[46]$} \\
\hline PEPc-pEERM & psbA2 & pepc from Synechocystis PCC 6803 & $\mathrm{Km}$ & psbA2 & {$[20]$} \\
\hline pEERM3+ & nrsB & - & $\mathrm{Sp}$ & NSI & {$[46]$} \\
\hline efe-pEERM3+ & $\mathrm{nrsB}$ & efe from $P$. syringae & Sp & NSI & This study \\
\hline pPMQAC 1 & psbA2 & - & $\mathrm{Cm}$ & Self-replicative vector & This study \\
\hline $\mathrm{PEPC}_{6803}-\mathrm{PPMQAC1}$ & psbA2 & pepc from Synechocystis PCC 6803 & $\mathrm{Cm}$ & Self-replicative vector & This study \\
\hline $\mathrm{PPSA}_{6803}-\mathrm{pPMQAC1}$ & psbA2 & ppsa from Synechocystis PCC 6803 & $\mathrm{Cm}$ & Self-replicative vector & This study \\
\hline $\begin{array}{l}\text { PPSA }_{6803}+ \\
\text { PEPC }_{6803}-\text { PPMQAC } 1\end{array}$ & psbA2 & ppsa and pepc from Synechocystis PCC 6803 & $\mathrm{Cm}$ & Self-replicative vector & This study \\
\hline $\mathrm{PEPC}_{7002}-\mathrm{PPMQAC} 1$ & psbA2 & pepc from Synechococcus PCC 7002 & $\mathrm{Cm}$ & Self-replicative vector & This study \\
\hline $\mathrm{PPSA}_{7002}-\mathrm{pPMQAC1}$ & psbA2 & ppsa from Synechococcus PCC 7002 & $\mathrm{Cm}$ & Self-replicative vector & This study \\
\hline $\begin{array}{l}\mathrm{PPSA}_{7002}+ \\
\mathrm{PEPC}_{7002}-\mathrm{PPMQAC} 1\end{array}$ & psbA2 & ppsa and pepc from Synechococcus PCC 7002 & $\mathrm{Cm}$ & Self-replicative vector & This study \\
\hline
\end{tabular}


Table 2 Engineered strains used/constructed in this study

\begin{tabular}{|c|c|c|}
\hline $\begin{array}{l}\text { Engineered } \\
\text { strains }\end{array}$ & Plasmid & References \\
\hline $\mathrm{WT}+\mathrm{Km} \mathrm{m}^{\mathrm{r}}$ & pEERM & {$[20]$} \\
\hline$W T+2 \times P E P C$ & PEPc-pEERM & {$[20]$} \\
\hline$C D-E$ & pEERM+pEERM3++pPMQAC1 & This study \\
\hline$C D-C$ & pEERM + efe-pEERM3++pPMQAC1 & This study \\
\hline$C D-P$ & PEPc-pEERM + efe-pEERM3++pPMQAC1 & This study \\
\hline CD-P1 & $\begin{array}{l}\text { PEPc-pEERM + efe-pEERM3++PEPC } 6803^{-} \\
\text {pPMQAC1 }\end{array}$ & This study \\
\hline CD-P2 & $\begin{array}{l}\text { PEPc-pEERM + efe-pEERM3 }++ \text { PPSA }_{6803^{-}} \\
\text {pPMQAC1 }\end{array}$ & This study \\
\hline CD-P3 & $\begin{array}{l}\text { PEPc-pEERM + efe- } \\
\text { pEERM3 + + PPSA } 6803+\text { PEPC }_{6803}-\text { PPMQAC1 }\end{array}$ & This study \\
\hline CD-P4 & $\begin{array}{l}\text { PEPc-pEERM + efe-pEERM3++PEPC }{ }_{7002^{-}} \\
\text {pPMQAC1 }\end{array}$ & This study \\
\hline CD-P5 & $\begin{array}{l}\text { PEPc-pEERM + efe-pEERM3 }++ \text { PPSA }_{7002^{-}} \\
\text {pPMQAC1 }\end{array}$ & This study \\
\hline CD-P6 & $\begin{array}{l}\text { PEPc-pEERM + efe- } \\
\text { pEERM3 }++ \text { PPSA }_{7002}+\text { PEPC }_{7002}-\text { pPMQAC1 }\end{array}$ & This study \\
\hline
\end{tabular}

at $150 \mathrm{rpm}$ with $\mathrm{LB}$ medium containing $\mathrm{Cm}\left(20 \mu \mathrm{g} \mathrm{mL} \mathrm{L}^{-1}\right)$ and ampicillin $\left(100 \mu \mathrm{g} \mathrm{mL} \mathrm{m}^{-1}\right)$, respectively. The cells were mixed in equal ratio and centrifuged for $5 \mathrm{~min}$ at $13,000 \mathrm{rpm}$. The pellet was resuspended in $200 \mu \mathrm{L}$ of $\mathrm{LB}$ and $20 \mu \mathrm{L}$ of the cells overexpressing PEPc and expressing Efe (CD_P) were mixed and incubated for $2-3 \mathrm{~h}$ at $30{ }^{\circ} \mathrm{C}$ under low light. The cells were spread on a nitrocellulose filter on top of BG11 agar plates. After approximately $24 \mathrm{~h}$ the filters were changed to a BG11 plate containing $\mathrm{Km}\left(25 \mu \mathrm{g} \mathrm{mL}^{-1}\right)$, Sp $\left(10 \mu \mathrm{g} \mathrm{m}^{-1}\right)$ and $\mathrm{Cm}$ $\left(20 \mu \mathrm{g} \mathrm{mL}^{-1}\right)$. Positive colonies were confirmed by PCR. The engineered strains are summarized in Table 2.

\section{Ethylene measurements}

$50 \mathrm{~mL}$ of the engineered Synechocystis cells were grown in BG11 with $\mathrm{Km}\left(25 \mu \mathrm{g} \mathrm{mL} \mathrm{m}^{-1}\right), \mathrm{Sp}\left(10 \mu \mathrm{g} \mathrm{mL} \mathrm{m}^{-1}\right)$ and $\mathrm{Cm}\left(20 \mu \mathrm{g} \mathrm{mL}^{-1}\right)$ under low light $\left(20 \mu \mathrm{E} \mathrm{m}^{-2} \mathrm{~s}^{-1}\right)$ until the $\mathrm{OD}_{750}$ was between 0.4 and 0.6 (determined using a Varian 50 Bio UV-Visible Spectrophotometer). The cells were harvested at $5000 \mathrm{rpm}$, for $15 \mathrm{~min}$ at room temperature. The pellet was then resuspended in $2 \mathrm{~mL}$ of BG11 with $\mathrm{Km}\left(25 \mu \mathrm{g} \mathrm{mL}^{-1}\right), \mathrm{Cm}\left(20 \mu \mathrm{g} \mathrm{mL}^{-1}\right), 50 \mathrm{mM}$ of Tris $\mathrm{pH} 8.0,50 \mathrm{mM}$ of $\mathrm{NaHCO}_{3}$ and with or without $5 \mu \mathrm{M}$ of $\mathrm{NiCl}_{2}$. Then, the $\mathrm{OD}_{750}$ were measured (determined using a Varian 50 Bio UV-Visible Spectrophotometer). The cells were then placed into headspace, $6 \mathrm{~mL}$ vial, clear glass-bevelled top and flat bottom vials from Sigma $(27,293)$ and completely sealed. The vials were placed shaking, under $20 \mu \mathrm{E} \mathrm{m}^{-2} \mathrm{~s}^{-1}$ for $24 \mathrm{~h}$.

After $24 \mathrm{~h}, 100 \mu \mathrm{L}$ of the gas phase was collected with a gas syringe and injected into a Clarus 580 Perkin Elmer FID gas chromatograph (GC) with a packed column $(1.8 \mathrm{~m} \times 2 \mathrm{~mm}$ i.d., Cat No. N9305013-ZW5531, Perkin Elmer). The carrier gas was $\mathrm{N}_{2}$ at $20 \mathrm{~mL} \mathrm{~min}^{-1}$. The GC program was $200{ }^{\circ} \mathrm{C}$ for $1 \mathrm{~min}$. The area of the ethylene peak at 0.4 min was converted into $\mathrm{mg} \mathrm{mL}^{-1}$ using the equation obtained from the standard curve. Pure ethylene was injected into the sealed vials and consequent dilutions were made.

When different treatments were used, the pellet was then resuspended in $2 \mathrm{~mL}$ of BG11 or BG11 $1_{0}$ with $\mathrm{Km}$ $\left(25 \mu \mathrm{g} \mathrm{mL}^{-1)}, \mathrm{Cm}\left(20 \mu \mathrm{g} \mathrm{mL}^{-1}\right), 50 \mathrm{mM}\right.$ of Tris pH 8.0, $50 \mathrm{mM}$ of $\mathrm{NaHCO}_{3}, 5 \mu \mathrm{M}$ of $\mathrm{NiCl}_{2}$ alone or with $50 \mu \mathrm{M}$

Table 3 Different treatments used in this study

\begin{tabular}{|c|c|c|c|c|}
\hline Treatment & Media & Addition & Action & Effect on the cells \\
\hline Standard & BG11 & - & & \\
\hline $\mathrm{BG} 11_{0}$ & $\mathrm{BG} 11_{0}$ & - & Nitrogen starvation & Higher substrate concentration: 2-oxoglutarate \\
\hline $\mathrm{BG} 11_{0}+\operatorname{Arg}$ & $\mathrm{BG} 11_{0}$ & Arginine & Nitrogen starvation and increased arginine & $\begin{array}{l}\text { Higher substrates concentration: 2-oxoglutarate and } \\
\text { arginine }\end{array}$ \\
\hline BG11+Arg & BG11 & Arginine & Increased arginine & Higher substrate concentration: arginine \\
\hline $\mathrm{BG} 11+\mathrm{Aza}$ & BG11 & Azaserine & $\begin{array}{l}\text { Inhibition of the glutamine amino transferase in the } \\
\text { glutamate synthase (GS-GOGAT cycle) }\end{array}$ & Higher substrate concentration: 2-oxoglutarate \\
\hline BG11+Cyclo & BG11 & Cycloxydim & Inhibition of acetyl-CoA carboxylase & Higher acetyl-CoA concentration \\
\hline BG11 $10+$ Cyclo & $\mathrm{BG} 11_{0}$ & Cycloxydim & $\begin{array}{l}\text { Nitrogen starvation and inhibition of acetyl-CoA } \\
\text { carboxylase }\end{array}$ & Higher 2-oxoglutarate and acetyl-CoA concentration \\
\hline $\begin{array}{l}\text { BG11+Arg+ } \\
\text { Aza+Cyclo }\end{array}$ & BG11 & $\begin{array}{l}\text { Arginine, } \\
\text { azaserine and } \\
\text { cycloxydim }\end{array}$ & $\begin{array}{l}\text { Increased arginine, inhibition of the glutamine } \\
\text { amino transferase in the glutamate synthase } \\
\text { (GS-GOGAT cycle) and inhibition of acetyl-CoA } \\
\text { carboxylase }\end{array}$ & $\begin{array}{l}\text { Higher arginine, 2-oxoglutarate and acetyl-CoA } \\
\text { concentration }\end{array}$ \\
\hline
\end{tabular}

In all treatments, $50 \mathrm{mM}$ Tris $\mathrm{pH} 8.0,50 \mathrm{mM} \mathrm{NaHCO}_{3}, \mathrm{Km}\left(25 \mu \mathrm{g} \mathrm{mL}^{-1}\right), \mathrm{Cm}\left(20 \mu \mathrm{g} \mathrm{mL}^{-1}\right)$ and $5 \mu \mathrm{M}$ of NiCl${ }_{2}$ were added and the cells were incubated, $24 \mathrm{~h}$ under $20 \mu \mathrm{mol}$ photons $\mathrm{m}^{-2} \mathrm{~s}^{-1}$ 
arginine, $100 \mu \mathrm{M}$ azaserine or $100 \mu \mathrm{M}$ cycloxydim or all combined. The treatments used are summarized in Table 3.

The experiments were done independently at least twice with three biological replicates each. The statistical analysis was performed using the Student's two-tailed $t$ test, $p<0.05$.

\section{SDS-PAGE and Western immunoblot (WB)}

After the ethylene measurements, 1 or $2 \mathrm{~mL}$ of cells were centrifuged $\left(5000 \mathrm{rpm}\right.$ for $10 \mathrm{~min}$ at $4{ }^{\circ} \mathrm{C}$ ) and the pellets were suspended with $2 \mathrm{~mL}$ of PBS buffer ([48] and Golden 2007), centrifuged (5000 rpm for $10 \mathrm{~min}$ ) before pellet resuspended in $200 \mu \mathrm{L}$ of PBS. Then $3 \mu \mathrm{L}$ of protease inhibitor (Protease Arrest ${ }^{\mathrm{TM}}[100 \times]$, Biosciences) was added. From this step the samples were always kept on ice. A glass beater $(6800 \mathrm{rpm}$ for $30 \mathrm{~s}$, three times, keeping the samples on ice for $5 \mathrm{~min}$ in between the $30 \mathrm{~s}$ intervals) was used in order to break the cells. $100 \mu \mathrm{L}$ of PBS buffer was added and the tubes were spun down for $30 \mathrm{~s}, 12,700 \mathrm{rpm}$ at $4{ }^{\circ} \mathrm{C}$. The supernatants were then transfer into clean Eppendorf tubes and centrifuged for $45 \mathrm{~min}, 12,700 \mathrm{rpm}$ at $4{ }^{\circ} \mathrm{C}$. The supernatant was then used to measure the soluble protein content of the samples by using the RC DC protein (Bio-Rad) kit. Albumin from bovine serum (Sigma) was used for the standard.

$3 \mu \mathrm{g}$ of protein was loaded on two Mini Protean TGXStain free gels (any $\mathrm{kDa}$ ) from Bio-Rad. The gels were run using a Mini-PROTEAN TGX ${ }^{\mathrm{TM}}$ system (Bio-Rad) for $35-40 \mathrm{~min}$ at 200 V. One gel was stained using Page Blue Protein staining gel from Thermo Scientific while the other was used for the blot using the Trans-Blot turbo transfer pack and system from Bio-Rad. The transfer was run at $25 \mathrm{~V}$ for $30 \mathrm{~min}$. After that the gel was stained with Coomassie blue (control) while the membrane was incubated with 5\% non-fat dried milk from AppliChem, for $1 \mathrm{~h}$ at room temperature under constant shaking. Then the membrane was washed $15 \mathrm{~min}$, three times with T-TBS. The mouse anti-FLAG antibody (monoclonal mouse from Agrisera (1:1000) was added onto the membrane for $1 \mathrm{~h}$ at room temperature under constant shaking. Thereafter, the membrane was washed with T-TBS as described above. The membrane was then incubated with an HRP-conjugated rabbit anti-mouse antibody from Agrisera (1:5000) for $1 \mathrm{~h}$ at room temperature under constant shaking. Finally the membrane was washed and developed using the Immuno-Star ${ }^{\mathrm{TM}}$ HRP- substrate kit (Bio-Rad) and the chemiluminescence reaction detected using a Chemi Doc XRS machine (Bio-Rad).

For the detection of PEPc, the procedure was the same as mentioned above except that $31 \mu \mathrm{g}$ of protein was loaded, ECL ${ }^{\mathrm{TM}}$ Blocking Agent from GE healthcare was used, incubated overnight at $4{ }^{\circ} \mathrm{C}$, the rabbit anti-PEPc antibody (polyclonal mouse from Agrisera (1:300) was incubated overnight at $4{ }^{\circ} \mathrm{C}$ and an $\mathrm{HRP}$-conjugated goat anti-rabbit from Agrisera (1:5000) was used.

\section{Sequence alignment}

The DNA and amino acid identity as well as the sequence alignment of PPSA from Synechocystis and Synechococcus was done using Clustal Omega.

\section{Supplementary information}

Supplementary information accompanies this paper at https://doi. org/10.1186/s13068-020-1653-y.

Additional file 1: Table S1. Primers used to amplify the ethylene forming enzyme (efe), phosphoenolpyruvate synthase (PPSA) and phosphoenolpyruvate carboxylase (PEPC) from Synechocystis PCC 6803 (subscript (6803) and Synechococcus PCC 7002 (subscript (7002). The forward primer (operon) has a RBS upstream of the starting codon in order to be placed in an operon after the phosphoenolpyruvate synthase (PPSA). PPSA forward primer contains a Flag tag (underlined). Figure S1. Sequence alignment of Phosphoenolpyruvate synthase from Synechocystis (PPSA PCC 6803) and Synechococcus (PPSA PCC 7002). An * indicates positions which have a single, fully conserved residue, : indicates conservation between groups of strongly similar properties-scoring >0.5 in the Gonnet PAM 250 matrix, indicates conservation between groups of weakly similar properties-scoring $\leq 0.5$ in the Gonnet PAM 250 matrix.

\section{Abbreviations}

Arg: arginine; Aza: azaserine; Cyclo: cycloxydim; EFE: ethylene-forming enzyme; PEPc: phosphoenolpyruvate carboxylase; PPSA: phosphoenolpyruvate synthase.

\section{Acknowledgements}

Not applicable.

\section{Authors' contributions}

CD designed all the experiments, generated all the genetic constructs, analysed the data and wrote the manuscript. PL contributed with scientific discussions and commented on the manuscript. JY sent a plasmid and commented on the manuscript. PL supervised the work and revised the manuscript. All authors read and approved the final manuscript.

\section{Funding}

Open access funding provided by Uppsala University. This work was supported by the NordForsk NCoE program "NordAqua" (project number 82845). It was authored in part by Alliance for Sustainable Energy, LLC, the manager and operator of the National Renewable Energy Laboratory for the U.S. Department of Energy (DOE) under Contract No. DE-AC36-08GO28308. Jianping Yu is supported by funding from DOE Office of Energy Efficiency and Renewable Energy BioEnergy Technologies Office. The views expressed in the article do not necessarily represent the views of the DOE or the U.S. Government. The U.S. Government retains and the publisher, by accepting the article for publication, acknowledges that the U.S. Government retains a nonexclusive, paid-up, irrevocable, worldwide license to publish or reproduce the published form of this work, or allow others to do so, for U.S. Government purposes.

\section{Availability of data and materials}

The data sets used and/or analysed during the current study are available from the corresponding author on reasonable request.

Ethics approval and consent to participate Not applicable.

Consent for publication

Not applicable. 


\section{Competing interests}

The authors declare that they have no competing interests.

\section{Author details}

${ }^{1}$ Microbial Chemistry, Department of Chemistry-Ångström, Uppsala University, P.O. Box 523, 75120 Uppsala, Sweden. ${ }^{2}$ Biosciences Center, National Renewable Energy Laboratory, Golden, CO, USA.

Received: 11 September 2019 Accepted: 9 January 2020 Published online: 28 January 2020

\section{References}

1. Stanier RY, Bazine GC. Phototrophic prokaryotes: the cyanobacteria. Annu Rev Microbiol. 1977;31:225-74.

2. Kasting JF, Siefert JL. Life and the evolution of Earth's atmosphere. Science. 2002:296:1066-8

3. Dvornyk V, Vinogradova O, Nevo E. Origin and evolution of circadian clock genes in prokaryotes. PNAS. 2003;100:2495-500.

4. Lambers H, Chapin FS, Pons TL. Photosynthesis, on plant physiological ecology. New York: Springer; 2008. p. 11-99.

5. Durall C, Lindblad P. Mechanisms of carbon fixation and engineering for increased carbon fixation in cyanobacteria. Algal Res. 2015:11:263-70.

6. Raven JA. Rubisco: still the most abundant protein of earth? New Phytol. 2013;198:1-3.

7. Eisenhut M, Huege J, Schwarz D, Bauwe H, Kopka J, Hagemann M. Metabolome phenotyping of inorganic carbon limitation in cells of the wild type and photorespiratory mutants of the cyanobacterium Synechocystis sp. strain PCC 6803. Plant Physiol. 2008;148:2109-20.

8. Price GD, Badger MR, Woodger FJ, Long BM. Advances in understanding the cyanobacterial $\mathrm{CO}_{2}$-concentrating-mechanism (CCM): functional components, Ci transporters, diversity, genetic regulation and prospects for engineering into plants. J Exp Bot. 2007;59:1441-61.

9. Kumar K, Dasgupta CN, Nayak B, Lindblad P, Das D. Development of suitable photobioreactors for $\mathrm{CO}_{2}$ sequestration addressing global warming using green algae and cyanobacteria. Bioresour Technol. 2011;102:4945-53.

10. Lindblad P, Lindberg P, Oliveira P, Stensjö K, Heidorn T. Design, engineering, and construction of photosynthetic microbial cell factories for renewable solar fuel production. Ambio. 2012;41:163-8.

11. Rosgaard L, de Porcellinis AJ, Jacobsen JH, Frigaard NU, Sakuragi Y. Bioengineering of carbon fixation, biofuels, and biochemicals in cyanobacteria and plants. J Biotechnol. 2012:162:134-47.

12. Miao R, Xie H, Lindblad P. Enhancement of photosynthetic isobutanol production in engineered cells of Synechocystis PCC 6803. Biotechnol Biofuels. 2018;11:267.

13. Atsumi S, Higashide W, Liao JC. Direct photosynthetic recycling of carbon dioxide to isobutyraldehyde. Nat Biotechnol. 2009;27:1177.

14. Chaiklahan R, Chirasuwan N, Loha V, Bunnag B. Lipid and fatty acids extraction from the cyanobacterium Spirulina. Sci Asia. 2008:34:299-305.

15. Liang F, Englund E, Lindberg P, Lindblad P. Engineered cyanobacteria with enhanced growth show increased ethanol production and higher biofuel to biomass ratio. Metabol Eng. 2018;46:51-9.

16. Douchi D, Liang F, Cano M, Xiong W, Wang B, Maness PC, Lindblad P, Yu J. Membrane-Inlet Mass Spectrometry enables a quantitative understanding of inorganic carbon uptake flux and carbon concentrating mechanisms in metabolically engineered cyanobacteria. Front Microbiol. 2019;10:1356.

17. Kanno M, Carroll AL, Atsumi S. Global metabolic rewiring for improved $\mathrm{CO}_{2}$ fixation and chemical production in cyanobacteria. Nat Commun 2017:8:14724.

18. Shih PM, Zarzycki J, Niyogi KK, Kerfeld CA. Introduction of a synthetic $\mathrm{CO}_{2}$-fixing photorespiratory bypass into a cyanobacterium. J Biol Chem. 2014;289:9493-500

19. Bar-Even A, Noor E, Lewis NE, Milo R. Design and analysis of synthetic carbon fixation pathways. PNAS. 2010;107:8889-94

20. Durall C, Rukminasari N, Lindblad P. Enhanced growth at low light intensity in the cyanobacterium Synechocystis PCC 6803 by overexpressing phosphoenolpyruvate carboxylase. Algal Res. 2016:16:275-81.
21. Ungerer J, Tao L, Davis M, Ghirardi M, Maness PC, Yu J. Sustained photosynthetic conversion of $\mathrm{CO}_{2}$ to ethylene in recombinant cyanobacterium Synechocystis 6803. Energy Environ Sci. 2012;5:8998-9006.

22. Kende H. Ethylene biosynthesis. Annu Rev Plant Biol. 1993;44:283-307.

23. Weingart H, Völksch B, Ullrich MS. Comparison of ethylene production by Pseudomonas syringae and Ralstonia solanacearum. J Phytopathol. 1999;89:360-5

24. Nagahama K, Ogawa T, Fujii T, Tazaki M, Tanase S, Morino Y, Fukuda H. Purification and properties of an ethylene-forming enzyme from Pseudomonas syringae pv. phaseolicola PK2. Microbiology. 1991;137:2281-6.

25. Muro-Pastor MI, Reyes JC, Florencio FJ. Cyanobacteria perceive nitrogen status by sensing intracellular 2-oxoglutarate levels. J Biol Chem. 2001;276:38320-8.

26. Sakai M, Ogawa T, Matsuoka M, Fukuda H. Photosynthetic conversion of carbon dioxide to ethylene by the recombinant cyanobacterium, Synechococcus sp. PCC 7942, which harbors a gene for the ethylene-forming enzyme of Pseudomonas syringae. J Ferment Bioeng. 1997;84:434-43.

27. Takahama K, Matsuoka M, Nagahama K, Ogawa T. Construction and analysis of a recombinant cyanobacterium expressing a chromosomally inserted gene for an ethylene-forming enzyme at the psbAl locus. J Biosci Bioeng. 2003;95:302-5.

28. Eckert C, Xu W, Xiong W, Lynch S, Ungerer J, Tao L, Gill R, Maness P, Yu J. Ethylene-forming enzyme and bioethylene production. Biotechnol Biofuels. 2014;7:33

29. Carbonell V, Vuorio E, Aro EM, Kallio P. Sequence optimization of Efe gene from $P$. Syringae is not required for stable ethylene production in recombinant Synechocystis sp. PCC 6803. Int J Innov Res Sci Eng Technol. 2016;4:30-5.

30. Veetil VP, Angermayr SA, Hellingwerf KJ. Ethylene production with engineered Synechocystis sp PCC 6803 strains. Microb Cell Fac. 2017;16:34.

31. Guerrero F, Carbonell V, Cossu M, Correddu D, Jones PR. Ethylene synthesis and regulated expression of recombinant protein in Synechocystis sp. PCC 6803. PLOS ONE. 2012;7:50470.

32. Zhu T, Xie X, Li Z, Tan X, Lu X. Enhancing photosynthetic production of ethylene in genetically engineered Synechocystis sp. PCC 6803. Green Chem. 2015;17:421-34

33. Xiong W, Morgan JA, Ungerer J, Wang B, Maness PC, Yu J. The plasticity of cyanobacterial metabolism supports direct $\mathrm{CO}_{2}$ conversion to ethylene. Nat Plants. 2015;1:15053.

34. Wang B, Eckert C, Maness PC, Yu J. A genetic toolbox for modulating the expression of heterologous genes in the cyanobacterium Synechocystis sp. PCC 6803. ACS Synth Biol. 2017:22:276-86.

35. Focke M, Lichtenthaler HK. Inhibition of the acetyl-CoA carboxylase of barley chloroplasts by cycloxydim and sethoxydim. Z Naturforschung $C$ 1987:42:1361-3.

36. Li H, Shen CR, Huang CH, Sung LY, Wu MY, Hu YC. CRISPR-Cas9 for the genome engineering of cyanobacteria and succinate production. Metabol Eng. 2016;38:293-302.

37. Lan El, Wei CT. Metabolic engineering of cyanobacteria for the photosynthetic production of succinate. Metabol Eng. 2016;38:483-93.

38. Carbonell V, Vuorio E, Aro EM, Kallio P. Enhanced stable production of ethylene in photosynthetic cyanobacterium Synechococcus elongatus PCC 7942. J Microbiol Biotechnol. 2019:35:77.

39. Mérida A, Candau P, Florencio FJ. Regulation of glutamine synthetase activity in the unicellular cyanobacterium Synechocystis sp. strain PCC 6803 by the nitrogen source: effect of ammonium. J Bacteriol. 1991;173:4095-100

40. Hauf W, Schlebusch M, Huege J, Kopka J, Hagemann M, Forchhammer K. Metabolic changes in Synechocystis PCC6803 upon nitrogen-starvation: excess NADPH sustains polyhydroxybutyrate accumulation. Metabolites. 2013;3:101-18

41. Stephan DP, Ruppel HG, Pistorius EK. Interrelation between cyanophycin synthesis, L-arginine catabolism and photosynthesis in the cyanobacterium Synechocystis sp. strain PCC 6803. Z Naturforschung C. 2000;55:927-42.

42. Wang B, Dong T, Myrlie A, Gu L, Zhu H, Xiong W, Maness P, Zhou RZ, Yu J. Photosynthetic production of the nitrogen-rich compound guanidine. Green Chem. 2019;21:2928-37.

43. Young JD, Shastri AA, Stephanopoulos G, Morgan JA. Mapping photoautotrophic metabolism with isotopically nonstationary 13C flux analysis. Metabol Eng. 2011;13:656-65. 
44. Ito S, Koyama N, Osanai T. Citrate synthase from Synechocystis is a distinct class of bacterial citrate synthase. Sci Rep. 2019;9:6038.

45. Takeya M, Hirai MY, Osanai T. Allosteric inhibition of phosphoenolpyruvate carboxylases is determined by a single amino acid residue in cyanobacteria. Sci Rep. 2017;7:41080

46. Englund E, Andersen-Ranberg J, Miao R, Hamberger B, Lindberg P. Metabolic engineering of Synechocystis sp. PCC 6803 for production of the plant diterpenoid manoyl oxide. ACS Synth Biol. 2015;4:1270-8.

47. Englund $E$, Liang F, Lindberg P. Evaluation of promoters and ribosome binding sites for biotechnological applications in the unicellular cyanobacterium Synechocystis sp. PCC 6803. Sci Rep. 2016;6:36640.
48. Ivleva NB, Golden SS. Protein extraction, fractionation, and purification from cyanobacteria, In: Rosato editors, Circadian rhythms. Methods in molecular biology; 2007 p. 365-73.

\section{Publisher's Note}

Springer Nature remains neutral with regard to jurisdictional claims in published maps and institutional affiliations.
Ready to submit your research? Choose BMC and benefit from:

- fast, convenient online submission

- thorough peer review by experienced researchers in your field

- rapid publication on acceptance

- support for research data, including large and complex data types

- gold Open Access which fosters wider collaboration and increased citations

- maximum visibility for your research: over 100M website views per year

At BMC, research is always in progress.

Learn more biomedcentral.com/submissions 